\author{
Praca poglądowa/Review paper
}

\title{
Historia badań nad rolą zapalenia w onkologii
}

\section{History of inflammation research in oncology}

\author{
Igor Piotrowski ${ }^{1,}$ Katarzyna Kulcenty $^{1}$, Wiktoria Suchorska ${ }^{1}$ \\ ${ }^{1}$ Pracownia Radiobiologi, Wielkopolskie Centrum Onkologii, Poznań, Polska
}

\begin{abstract}
Streszczenie
Przebieg procesu zapalnego w ciele człowieka obserwowano i opisywano już w czasach starożytnych. Wraz z rozwojem współczesnej patologii i immunologii w XIX i XX wieku zaczęto obserwować powiązania między nowotworzeniem a reakcją zapalną. Choć pierwsze doniesienia łączące ze sobą te dwa procesy datuje się na pierwszą połowę XIX wieku, to dopiero dalsze badania pozwoliły na zrozumienie oddziaływania tych procesów. Najnowsze doniesienia coraz częściej pokazują, że reakcja zapalna odgrywa bardzo ważną rolę w progresji choroby nowotworowej. Proces nowotworzenia w wielu przypadkach, jak na przykład nowotwory przewodu pokarmowego, rozpoczyna się od przewlekłego zapalenia i infekcji. Obecnie wiemy także, że reakcja zapalna często występuje w mikrośrodowisku nowotworu stymulując proliferację i migrację komórek nowotworowych. Celem tej pracy jest przybliżenie historii badań nad reakcją zapalną w nowotworzeniu, od pierwszej obserwacji tej zależności do najnowszych doniesień.
\end{abstract}

\footnotetext{
Abstract

Adres do korespondencji

Igor Piotrowski

Zakład Radioterapii I,

Wielkopolskie Centrum Onkologii, ul. Garbary 15, 61-866 Poznań, Polska

Telefon. +48618850474

e-mail: igor.piotrowski@wco.pl
}

Inflammatory reaction in human body was first observed and described in ancient history dating as far back as 2700 BCE. During the development of modern pathology and immunology in XIX and XX century researchers started to notice connection between carcinogenesis and inflammation. First reports linking the two phenomenon date back to the first half of XIX century and further research allowed deeper understanding of the role of inflammation in cancer. Current data show, that inflammation is a crucial part of progression of tumour. Carcinogenesis is often initiated by chronic inflammation and infection, like in gastrointestinal cancers. Inflammatory reaction is also observed in microenvironment of the tumour, 
stimulating proliferation and migration of cancer cells. This review summarises the history of research on inflammation and cancer, from the first observation of the connection between the two phenomenon to the most recent findings.

Stowa kluczowe: zapalenie, onkologia, nowotworzenie, historia

Keywords: inflammation, oncology, carcinogenesis, history

\section{Badania nad procesem zapalnym}

Proces zapalny został odkryty i po raz pierwszy opisany już w czasach starożytnych przez Egipcjan, Greków i Chińczyków. Pierwszy zapis słowa oznaczającego zapalenie pojawił się na papirusie, który datowany jest na 2700 lat p.n.e. [1]. Naukowy opis tego procesu oraz jego objawów po raz pierwszy pojawił się w pierwszym wieku naszej ery w encyklopedii „De Medicina” autorstwa Aulusa Corneliusa Celsusa, który zdefiniował cztery podstawowe symptomy zapalenia: zaczerwienienie, opuchlizna z towarzyszącym jej ociepleniem oraz ból [2]. W drugim wieku naszej ery, rzymski chirurg, Galen zdefiniował stan zapalny jako wczesny objaw procesu gojenia uszkodzonych tkanek, którego wystąpienie korelowało z wyzdrowieniem. Niektórzy przypisują mu także określenie piątego objawu reakcji zapalnej, tj. utraty funkcji tkanki objętej zapaleniem, jednakże większość naukowców uważa, że termin functionlaesa został wprowadzony w roku 1871 przez Rudolfa Ludwiga Carla Virchowa.

W XVIII wieku wiedza na temat zapalenia została pogłębiona dzięki doświadczeniom szkockiego anatoma Johna Huntera. Jego prace badawcze nad zapaleniem zapoczątkowane były w roku 1760, kiedy Hunter służył jako chirurg w trakcie wojny siedmioletniej w Portugalii [3]. Swoje obserwacje oraz doświadczenia z tego czasu, a także z eksperymentów wykonywanych później, zawarł w dziele „Treatise on the Blood, Inflammation and GunshotWounds”, wydanym pośmiertnie w roku 1794. Hunter opisuje tam zapalenie wywołane obrażeniami zewnętrznymi, a także obrażeniami wewnętrznymi (np. rany postrzałowe) oraz rozróżnia etapy zapalenia pojawiające się w trakcie gojenia rany. Hunter zauważył, że proces zapalny należy traktować nie jako stan nieprawidłowy, a jako korzystną odpowiedź organizmu na „przemoc lub chorobę" [1]. Zapalenie przed XVIII wiekiem było uważane za konkretną jednostkę chorobową, zdefiniowaną przez cztery objawy opisane przez Celsusa. Hunter prawdopodobnie jako pierwszy zwrócił uwagę na różnicę między przyczyną zapalenia a reakcją tkankową na tę przyczynę. Klasyfikacja procesu zapalnego spisana przez Huntera wywołała bardzo duży wpływ na badania w tej dziedzinie w dziewiętnastym i dwudziestym wieku. Jego odkrycia cytowane są przez Virchowa[4] oraz Pageta[5], a także miały duży wpływ na prace Josepha Listera [6].

W XIX i XX wieku badania nad zapaleniem prowadzone były przez wybitnego Niemieckiego patologa, antropologa, lekarza i biologa Rudolfa Virchowa oraz jego ucznia Juliusza Cohnheima. Virchow jako jeden z pierwszych wykorzystał mikroskop, uważany ówcześnie głównie za ciekawostkę, do badań nad komórkowym charakterem procesu zapalnego. W oparciu o swoje badania w 1859 roku Virchow opublikował książkę o tytule „DieCellularpathologie” - Patologia Komórkowa [4]. Virchow uważał, że proces zapalny wywodzi się ze zwiększonej aktywności komórek, które poszukują odpowiedniego źródła substancji odżywczych w otaczających je tkankach; uznał, że reakcja zapalna jest konsekwencją nadmiernego poboru substancji odżywczych zawartych w płynnej frakcji krwi przenikającej przez ścianę naczyń krwionośnych. Zaobserwował także, że ropa powstająca w wyniku procesu zapalnego zawiera „ciałka”, jednakże uważał, że nie ma dowodów na to, że są to leukocyty migrujące z krwioobiegu. Badania prowadzone przez Henri Dutrocheta i Augusta Wallera opublikowane w 1824 oraz w 1846 roku wykazały, że leukocyty są zdolne do migracji poza naczynia krwionośne, oraz że komórki zawarte w ropie to w rzeczywistości leukocyty, które migrowały przez ścianę naczyń kapilarnych [1]. Prace te początkowo nie były znane Virchowowi a zjawisko to zostało ponownie zbadane przez jego ucznia Juliusza Cohnheima. Cohnheim opublikował wyniki swoich badań w pracy „UeberEntzündungundEiterung” (O zapaleniu i sepsie), w której opisał mechanizm powstawania zapalenia, i stwierdził, że leukocyty obecne w lokacji zapalenia migrują z krwioobiegu, a pochodzą ze szpiku [7]. Znaczna część odkryć Cohnheima jest bezpośrednim skutkiem prowadzonych przez niego badań na zwierzętach. Badając proces zapalny w podrażnionym języku żywej żaby zaobserwował 
początkowe rozszerzenie się naczyń krwionośnych i zwiększony napływ krwi, który następnie zwalniał po czym następowało przejście białych krwinek do tkanki z towarzyszącym wysiękiem osocza [7]. Chociaż rozszerzenie naczyń krwionośnych zostało zaobserwowane już w badaniach Huntera na odmrożonych uszach królików, to Cohnheim po raz pierwszy poprawnie opisał sekwencję zdarzeń towarzyszących zapaleniu ostremu. Dzięki tym obserwacjom mógł opisać przyczyny czterech objawów zapalenia opisanych przez Celsusa: zaczerwienienie i ocieplenie tkanki są konsekwencją zwiększonego napływu krwi, zaś opuchlizna i ból wynikają z nagromadzenia wysięku osocza w tkance.

Dalszy rozwój wiedzy na temat roli komórek układu odpornościowego w odpowiedzi zapalnej był możliwy dzięki badaniom prowadzonym przez Ilję Miecznikowa. W roku 1883 w wykładzie zatytułowanym „Forcescuratives de l’organisme” Miecznikow porównał leukocyty do „armii, która rzuca się na przeciwnika”. Dzięki badaniom z wykorzystaniem rozwielitek oraz larw rozgwiazdy odkrył zjawisko fagocytozy określające zdolność komórek do pochłonięcia i strawienia obcych mikro-organizmów. Zdolność ta była według niego kluczowym procesem dzięki któremu leukocyty uczestniczą w ochronie organizmu przed infekcjami [8]. Naukowcy zaobserwowali pobieranie bakterii przez białe komórki krwi na długo przed badaniami Miecznikowa, jednakże początkowo uważano, że proces fagocytozy bakterii przez krwinki przede wszystkim przyczynia się do rozprzestrzeniania zakażenia. W przekonaniu Miecznikowa zapalenie ma na celu doprowadzenie fagocytów do uszkodzonej tkanki dzięki zjawisku rozszerzenia naczyń i zwiększenia przepływu krwi, które nie są zmianami patologicznymi a fizjologicznymi. Za badania nad fagocytozą Miecznikow otrzymał Nagrodę Nobla w 1908 roku. W swoich dalszych badaniach Miecznikow opisał także makrofagi oraz układ siateczkowo-śródbłonkowy.

W późniejszych latach Sir Thomas Lewis odkrył czynnik zapalny - histaminę, przeprowadzając eksperyment, w którym wywoływał reakcję zapalną skóry poprzez przeciągnięcie po niej linijką [9]. Lewis zaobserwował, że następująca sekwencja zdarzeń: pojawienie się czerwonej linii, wystąpienie zaczerwienienia wokół, a następnie powstanie opuchlizny, wiąże się z degranulacjąmastocytów i uwolnieniem z nich histaminy. Histamina rozszerza naczynia krwionośne a także zwiększa ich przepuszczalność skutkując wysiękiem osocza do tkanki i obrzękiem. W roku 1978 Maurício Rocha e Silva opisał reakcję zapalną od strony biochemicznej, odkrył kolejny ważny czynnik biorący udział w zapaleniu - bradykininę, oraz opisał cechy definiujące mediator zapalenia [10]. Wszystkie te odkrycia przyczyniły się do lepszego zrozumienia reakcji zapalnej jako odpowiedzi na uszkodzenia lub infekcje, a także pozwoliły na późniejsze powiązanie tego procesu z nowotworzeniem.

\section{Proces zapalny a nowotworzenie}

Pierwsze powiązania między przewlekłym procesem zapalnym a nowotworzeniem zostały zaobserwowane już w 1828 roku przez francuskiego chirurga Jeana Nicholasa Marjolina. Zaobserwował on powstanie raka płaskonabłonkowego skóry w pobliżu stanu zapalnego towarzyszącego otwartej ranie [11]. Pierwotnie Marjolin nie nazwał tych zmian nowotworowymi, a jedynie rodzajem owrzodzeniem, jednak opis przypadku zgadza się z charakterystyką raka płaskonabłonkowego. Dalsze badania nad owrzodzeniami nowotworowymi były prowadzone przez Caesara Hawkinsa, Angielskiego chirurga, który w roku 1833 opisał przypadki wystąpienia raka skóry w miejscu blizn po oparzeniach oraz starych blizn pozostałych po chłoście [12]. Trzydzieści lat później Rudolf Virchow zaobserwował obecność leukocytów w tkance zmienionej nowotworowo i wymienił przewlekłą reakcję zapalną jako jedną z kilku przyczyn powstawania raka [13]. Virchow sugerował, że powstanie raka związane jest z czynnikami limforetikularnymi infiltrującymi miejsce zapalenia, jednakże uważał także, że to nie komórki nowotworowe, a infekcja jest powodem rozsiania nowotworu. Virchow zauważył, że rozprzestrzenianie się nowotworu zależy od jego unaczynienia: nowotwory o słabszym unaczynieniu „infekują” (obecnie proces ten nazwalibyśmy przerzutowaniem) jedynie okoliczne tkanki, zaś im więcej krwi i limfy przepływa przez guza, tym łatwiej rozprzestrzeni się „infekcja nowotworem” [14]. W roku 1872 Waldeyer dodał, że oprócz czynników immunologicznych, do powstania nowotworu kluczowe jest wcześniejsze wystąpienie zaburzeń tkanki łącznej [15]. Na początku XX wieku patolog Bernard FischerWasels wysunął hipotezę jakoby nowotworzenie związane z długotrwałym zapaleniem miało następować przez nadmiernie aktywowane procesy gojenia ran [16].

$\mathrm{Na}$ początku XX wieku pojawiły się pierwsze opisy spontanicznej regresji nowotworów związanej 
z układem immunologicznym, a także wzrosło zainteresowanie odpowiedzią gospodarza w zwierzęcych modelach nowotworów. Handley zaobserwował, że infiltracja czerniaka złośliwego przez komórki układu odpornościowego zaindukowała proces regresji nowotworu [17]. Dokładna cytologiczna analiza guzów indukowanych w immunizowanych myszach doprowadziła do konkluzji, że kumulacja komórek układu odpornościowego wokół guza jest wyrazem reakcji podobnej do odpowiedzi immunologicznej (18). Dalsze postępy w badaniu procesu nowotworzenia towarzyszyły coraz silniejszemu przekonaniu, że sam przewlekły proces zapalny nie jest wymagany do wzrostu guza. W roku 1940 James Ewing napisał, że „reakcja zapalna często zbiega się z inwazją komórek nowotworowych (...) i należy ją traktować jako proces obronny” [19].

Obecnie wiedza na temat powiązania między reakcją zapalną a nowotworzeniem jest znacznie większa niż w czasach Marjolina czy Virchowa. Szacuje się, że około 25\% wszystkich przypadków raka jest rezultatem przewlekłego procesu zapalnego wywołanego infekcją, chorobami związanymi z zapaleniem (np. zapalenie gruczołu krokowego) lub paleniem papierosów [20]. Dodatkowo nowotwory, które nie są epidemiologicznie związane z zapaleniem, charakteryzują się obecnością komórek zapalnych w obrębie guza, zaś samo mikrośrodowisko guza jest bogate w cytokiny zapalne, czynniki wzrostu oraz chemokiny promujące wzrost komórek nowotworowych. Czynniki te wytwarzane są zarówno przez komórki guza jak i przez otaczającą go tkankę i przyczyniają się do zezłośliwienia guza. Można wyróżnić dwa rodzaje procesu zapalnego związanego z nowotworem: zapalenie występujące przed powstaniem nowotworu, oraz zapalenie obecne w prawie wszystkich tkankach zmienionych nowotworowo, włączając $\mathrm{w}$ to zmiany nie wywołane przez zapalenie [21]. Przewlekłe wystawienie tkanki na działanie mediatorów zapalenia jak kwas arachidonowy, cytokiny, chemokiny oraz wolne rodniki prowadzi do zwiększonej proliferacji komórek, mutagenezy, aktywacji onkogenów oraz angiogenezy.

Nowotworzenie jest procesem skomplikowanym, i w uproszczeniu jego przebieg opiera się o trzy złożone fazy: inicjację, promocję i progresję choroby. Po raz pierwszy procesy te zostały opisane w latach 40. XX wieku, dzięki badaniom nad mysim modelem raka skóry [22]. Inicjacja procesu nowotworzenia wiąże się z nagromadzeniem mutacji w DNA (mutacja punktowa, delecja, amplifikacja), metylacji lub rearanżacji genów lub chromosomów, które nie mogą zostać naprawione i prowadzą do przyspieszenia wzrostu komórkowego [23]. W wielu przypadkach inicjacja jest indukowana przez działanie genotoksycznych czynników rakotwórczych, które powodują uszkodzenia DNA. Druga faza, promocja, opiera się o klonalny wzrost komórki zmienionej w fazie inicjacji. Promocja jest możliwa dzięki zmianom genetycznym i epigenetycznym indukującym zwiększoną proliferację komórek. Progresja oznacza uzyskanie fenotypu złośliwego przez klon komórek wcześnie nowotworowych. Są do tego wymagane zarówno mechanizmy genetyczne jak i epigenetyczne, a zmienione w ten sposób komórki nie odpowiadają na sygnały regulujące wzrost, co prowadzi do niekontrolowanego rozrostu guza. W jaki sposób jednak reakcja zapalna może prowadzić do nowotworzenia?

W trakcie przewlekłego zapalenia duża liczba komórek układu immunologicznego migruje do miejsca zapalenia tworząc mikrośrodowisko sprzyjające rozwojowi nowotworu. W przewlekłej reakcji zapalnej mikrośrodowisko jest zdominowane przez obecność makrofagów [24]. Makrofagi i limfocyty T mogą uwalniać czynnik martwicy nowotworów (TNF- $\alpha$, Tumor NecrosisFactor- $\alpha$ ) i czynnik zahamowania migracji makrofagów [25]. TNF- $\alpha$ pośrednio przyczynia się do zwiększenia angiogenezy guza, migracji komórek nowotworowych w stronę naczyń krwionośnych, a także ma zdolność stymuluje proliferację i hamuje apoptozę w tych komórkach. Czynnik zahamowania migracji makrofagów blokuje zależną od białka p53 odpowiedź ochronną przed uszkodzeniami DNA, co powoduje akumulację mutacji onkogennych. Makrofagi związane z nowotworami (ang. tumor-associatedmacrophages, TAM) przyczyniają się do rozwoju nowotworu na kilku drogach. Komórki te mogą uwalniać interleukinę 10 oraz prostaglandynę E2, które hamują odpowiedź przeciwnowotworową. TAM uwalniają czynnik wzrostu śródbłonka naczyniowego(VEGF) zwiększający unaczynienie guza, a także metaloproteinazy macierzy pozakomórkowej, które umożliwiają inwazję i przerzutowanie komórek nowotworowych [26]. Rola wielu komórek układu odpornościowego w nowotworzeniu nie jest jeszcze dokładnie poznana.

Znaczną rolę w odpowiedzi zapalnej odgrywają reaktywne formy tlenu (ang. reactiveoxygenspecies, ROS) oraz azotu (ang. reactivenitrogenspecies, RNS) produkowane przez komórki zapalne i epitelialne[27]. ROS oraz RNS powodują uszkodzenia różnych składników komórkowych jak materiał genetyczny, białka i lipidy. Obecność reaktywnych form tlenu może prowadzić do indukcji oksydacyjnych uszkodzeń DNA jak 
powstanie 8-oksy-2'deoksyguanozyny, która podczas replikacji DNA prowadzi do transwersji G na T [28]. Reaktywne formy azotu również mogą prowadzić do indukcji mutacji. Tlenek azotu jest syntetyzowany przez syntazy tlenku azotu, które występują w trzech izoformach. Jedna z nich - indukowalna syntaza tlenku azotu, jest silnie aktywowana w komórkach układu odpornościowego i komórkach epitelialnych w czasie zapalenia i dodatkowo jej aktywność wzrasta na skutek działania czynników jak NK-kB, HIF1- $\alpha$, STAT i TNF- $\alpha$, które są obecne w trakcie reakcji zapalnej [29]. Tlenek azotu wchodzi w reakcję z anionorodnikiem ponadtlenkowym $\left(\mathrm{O}_{2}{ }^{--}\right)$tworząc nadtlenoazotyn, silnie reaktywną formę azotu, która powoduje powstanie 8-oksy-2'deoksyguanozyny oraz 8-nitroguaniny mających działanie mutagenne i mogących prowadzić do powstania nowotworu [30]. Długotrwałe uszkodzenie tkanki oznacza długi czas narażenia proliferujących komórek nabłonka i komórek zrębu na czynniki mutagenne, co dodatkowo zwiększa ryzyko rozwoju zmiany nowotworowej.

Wiele chorób związanych z zapaleniem może predysponować komórki do przejścia transformacji nowotworowej. Większość z powstałych na tej drodze nowotworów ma pochodzenie nabłonkowe. Najwięcej dowodów na powiązanie między chorobą zapalną na nowotworzeniem istnieje dla: raka jelita grubego związanego z nieswoistym zapaleniem jelit (choroba Leśniewskiego-Crohna i wrzodziejące zapalenie jelita grubego), raka przełyku związanego z przełykiem Baretta, zapalenia wątroby predysponującego do raka wątroby, schistosomatozy wywołującej zwiększone ryzyko raka pęcherza i jelita grubego oraz przewlekłej infekcji Helicobacterpylori prowadzącej do raka żołądka [24]. Pacjenci z nieswoistym zapaleniem jelit wykazują pięć do siedmiu razy zwiększone ryzyko rozwinięcia raka jelita grubego [31].

Reakcja zapalna może odgrywać rolę nie tylko w powstaniu nowotworu, ale także w jego nawrocie po terapii. Chirurgiczne wycięcie guza jest najstarszą metodą terapii, i stanowi filar współczesnego leczenia i kontroli większości nowotworów litych. Chociaż chirurgiczne wycięcie guza pierwotnego czy przerzutów może uratować lub wydłużyć życie, od ponad wieku wiadomo, że taka procedura może zwiększyć ryzyko powstania nawrotu. Zależność między wycięciem guza a zwiększonym ryzykiem nawrotu po raz pierwszy odnotowali Paget i Halsted, którzy na początku XX wieku zaobserwowali, że pacjenci, którzy przeszli resekcję guza nie przeżywali tak długo jak pacjenci którzy zamiast operacji pozostawali pod obserwacją [32]. Początkowo doniesienia te uznano za pojedyncze przypadki nie wskazujące na żaden trend, jednakże nowsze dowody pokazały, że interwencja chirurgiczna może powodować powstanie mikrośrodowiska przyjaznego wzrostowi lokalnej wznowy, a także może przyspieszać wzrost odległych przerzutów [33]. W procesie tym bardzo ważną rolę odgrywa lokalne zapalenie, a także następujące po nim procesy gojenia. W ostatnich latach pojawia się coraz więcej badań dotyczących potencjalnie pronowotworowego, związanego z zapaleniem, efektu wycięcia guza.

\section{Podsumowanie}

Zarówno zapalenie oraz nowotworzenie są skomplikowanymi procesami, których przebieg zależy od wielu różnych sygnałów. Początkowo uważano, że reakcja zapalna jest wynikiem patologicznych podziałów komórek spowodowanych wysiękiem substancji odżywczych poza naczynia krwionośne, a także że komórki krwi umożliwiają rozwój infekcji [4]. Jednakże badania z wykorzystaniem modeli zwierzęcych, a także obserwacje procesu zapalnego u ludzi pozwoliły na rozpoznanie jego roli w odpowiedzi organizmu na uszkodzenie lub infekcję. Obecnie wiele badań bezpośrednio powiązuje przewlekły proces zapalny z nowotworzeniem a także z przerzutowaniem i z powstawaniem nawrotów [33]. Dalsze badania nad opisaniem mechanizmu zapalenia i jego związku z nowotworzeniem pozwolą na rozwój metod zapobiegania powstawania nowotworów oraz ich terapii.

\section{Bibliografia}

[1] Majno G, Joris I. Cells, tissues, and disease : principles of general pathology. 2nd ed. New York: Oxford University Press; 2004. xxviii, 1005 p. p.

[2] Rocha e Silva M. A brief survey of the history of inflammation. Agents Actions. 1978;8(1-2):45-9.

[3] Turk JL. Inflammation: John Hunter's “A treatise on the blood, inflammation and gun-shot wounds". Int J Exp Pathol. 1994;75(6):385-95. 
[4] Virchow R. Cellularpathologie. 4th, editor. Berlin: August Hirschwald; 1971.

[5] Paget J. Lectures on surgical pathology, delivered at the Royal college of surgeons of England. London,: Longman, Brown, Green, and Longmans; 1853.

[6] Godlee RJ. Lord Lister. 2d ed. London,: Macmillan and co., limited; 1918. xix, 681 p.

[7] Cohnheim J. Über Entzündung und Eiterung: Springer-Verlag; 1867.

[8] Dubos RJ. The micro-environment of inflammation or Metchnikoff revisited. Lancet. 1955;269(6879):15 .

[9] Lewis T. The Blood Vessels of the Human Skin. Br Med J. 1926;2(3418):61-2.

[10] Scott A, Khan KM, Cook JL, Duronio V. What is "inflammation"? Are we ready to move beyond Celsus? Br J Sports Med. 2004;38(3):248-9.

[11] Bazalinski D, Przybek-Mita J, Baranska B, Wiech P. Marjolin's ulcer in chronic wounds - review of available literature. Contemp Oncol (Pozn). 2017;21(3):197-202.

[12] Hawkins C. Cases of Warty Tumours in Cicatrices. Med Chir Trans. 1835;19:19-34.

[13] Balkwill F, Mantovani A. Inflammation and cancer: back to Virchow? Lancet. 2001;357(9255):539-45.

[14] Schmidt A, Weber OF. In memoriam of Rudolf virchow: a historical retrospective including aspects of inflammation, infection and neoplasia. Contrib Microbiol. 2006;13:1-15.

[15] Waldeyer W. Die Entwickelung der Carcinome: Virchows Arch. path. Anat.; 1872.

[16] Haddow A. Addendum to "molecular repair, wound healing, and carcinogenesis: tumor production a possible overhealing"? Adv Cancer Res. 1974;20:343-66.

[17] Handley W. The Pathology of melanotic growths in relation to their operative treatment: The Lancet; 1907.

[18] Da Fano C. A Cytological Analysis of the Reaction in Animals Resistant to Implanted Carcinomata: Sci Rep Imp Cancer Res Fund; 1912.

[19] Ewing J. Neoplastic diseases; a treatise on tumors. Philadelphia and London,: W. B. Saunders company; 1940. xii, 1160 p. p.

[20] Balkwill FR, Mantovani A. Cancer-related inflammation: common themes and therapeutic opportunities. Semin Cancer Biol. 2012;22(1):33-40.

[21] Shacter E, Weitzman SA. Chronic inflammation and cancer. Oncology (Williston Park). 2002;16(2):21726, 29; discussion 30-2.

[22] Berenblum I, Shubik P. A new, quantitative, approach to the study of the stages of chemical cartinogenesis in the mouse's skin. Br J Cancer. 1947;1(4):383-91.

[23] Hanahan D, Weinberg RA. The hallmarks of cancer. Cell. 2000;100(1):57-70.

[24] Coussens LM, Werb Z. Inflammation and cancer. Nature. 2002;420(6917):860-7.

[25] Pollard JW. Tumour-educated macrophages promote tumour progression and metastasis. Nat Rev Cancer. 2004;4(1):71-8.

[26] Lu H, Ouyang W, Huang C. Inflammation, a key event in cancer development. Mol Cancer Res. 2006;4(4):221-33.

[27] Ohshima H, Tatemichi M, Sawa T. Chemical basis of inflammation-induced carcinogenesis. Arch Biochem Biophys. 2003;417(1):3-11.

[28] Bruner SD, Norman DP, Verdine GL. Structural basis for recognition and repair of the endogenous mutagen 8-oxoguanine in DNA. Nature. 2000;403(6772):859-66.

[29] Wang S, Liu Z, Wang L, Zhang X. NF-kappaB signaling pathway, inflammation and colorectal cancer. Cell Mol Immunol. 2009;6(5):327-34.

[30] Ma N, Murata M, Ohnishi S, Thanan R, Hiraku Y, S K. 8-Nitroguanine, a Potential Biomarker to Evaluate the Risk of Inflammation-Related Carcinogenesis. In: TK K, editor. Biomarker. Croatia: InTech; 2012.

[31] Ekbom A, Helmick C, Zack M, Adami HO. Ulcerative colitis and colorectal cancer. A population-based study. N Engl J Med. 1990;323(18):1228-33.

[32] Halsted WS. I. The Results of Radical Operations for the Cure of Carcinoma of the Breast. Ann Surg. 1907;46(1):1-19.

[33] Demicheli R, Retsky MW, Hrushesky WJ, Baum M, Gukas ID. The effects of surgery on tumor growth: a century of investigations. Ann Oncol. 2008;19(11):1821-8. 